\title{
Assessment of environmental quality through analysis of frequency of the black spot disease in an assemblage of fish, Guaíba lake, RS, Brazil
}

\author{
Flores-Lopes, F. ${ }^{a, b *}$ and Thomaz, AT. ${ }^{a}$

\begin{abstract}
aPrograma de Pós-graduação em Biologia Animal, Laboratório de Ictiologia, Departamento de Zoologia, CEP 90540-000, Porto Alegre, RS, Brazil

bDepartamento de Ciências Biológicas, Universidade Estadual de Santa Cruz - UESC, Rod. Ilhéus-Itabuna, Km 16, CEP 45650-900, Ilhéus, BA, Brazil

*e-mail: fabiologo5@ hotmail.com
\end{abstract} \\ Universidade Federal do Rio Grande do Sul - UFRGS, Av. Bento Gonçalves, 9500, Bloco IV, Prédio 43435,
}

Received August 11, 2010 - Accepted December 12, 2010 - Distributed November 30, 2011

(With 4 figures)

\begin{abstract}
The frequency of the black spot disease caused by digenetic trematodes in fish was tested as an indicator of the quality of water in the watershed of Lake Guaíba. Samples were standardised and quarterly made using a seine net at eleven sites in the basin. A total of 53,408 individuals of 66 specimens pertaining to 22 families and 8 orders were collected and analysed. The highest frequency of the disease was found in Astyanax fasciatus. The simple Chi-Squared test applied to the species showed statistically significant frequency of occurrence for three sampled sites. Two of these sites showed the highest frequencies for two consecutive sampling periods of one year and the best levels of water quality. Results of this study suggest that the association between high frequency of infestation by a parasite that causes the black spot disease in fish, and environments with less degradation in water quality, recorded from physical, chemicals and microbiological variables, could be used as an indicator of water quality in these environments.
\end{abstract}

Keywords: black spot disease, environmental quality, Astyanax fasciatus, Guaíba Lake, RS, Brazil.

\section{Avaliação da qualidade ambiental através da análise da frequência da doença dos pontos pretos em assembléias de peixes, Lago Guaíba, RS, Brasil}

\section{Resumo}

A frequência da doença dos pontos pretos, provocada por trematódeos digenéticos em peixes, foi testada como indicador da qualidade da água na bacia hidrográfica do lago Guaíba (RS). As amostragens foram padronizadas e realizadas trimestralmente com redes do tipo picaré em onze pontos desta bacia. Foram coletados e analisados 53.408 exemplares, totalizando 66 espécies pertencentes a 22 famílias e oito ordens. A maior frequência de ocorrência da doença foi verificada em Astyanax fasciatus. Um Qui-Quadrado simples aplicado para essa espécie indicou frequência estatisticamente significativa de ocorrência da doença para três locais amostrados. Dois destes locais apresentaram as maiores frequências durante dois períodos consecutivos de um ano de amostragem e os melhores níveis de qualidade de água. Os resultados deste trabalho sugerem que a associação entre a elevada frequência de infestação pelo parasito que causa a doença dos pontos pretos e os ecossistemas com menor degradação na qualidade da água, com registros de variáveis físicas, químicas e microbiológicas, pode ser utilizada como indicador de melhor qualidade ambiental.

Palavras-chave: pontos pretos, qualidade ambiental, Astyanax fasciatus, lago Guaíba, RS, Brasil. 


\section{Introduction}

Deterioration of the environment due to human activities has led to the development and adequacy of evaluation methods on environmental quality (Bruschi Junior et al., 2000). Based on that, biological methods have been increasingly used in environmental studies, due to the response of some organisms to small changes that occur in the environment where they live for a certain time interval (Lobo et al., 2002).

Chemical, physical and biological stress affect the biological characteristics of aquatic environments (Gibson et al., 1996) and may result in the extinction of vulnerable species, thereby showing changes in the conditions and functions of the biotic community. Interactions between these different kinds of stress and their cumulative impacts on organisms underscore the need to detect and directly assess the biota as an indicator of the current sources of degradation of the aquatic environment (Barbour et al., 1999). Impact of a stress is variable in population dynamics of hosts and parasites, and it may also be physiologically or behaviourally expressed in these organisms (Esch, 1974). The same stress may influence positively or negatively, depending on the species involved and the conditions existing at that time, since the free-living stages of parasites may be vulnerable to environmental conditions (Marcogliese and Cone, 1997).

Pollutants may directly affect the immunological system of fish, or through changes wrought in aquatic environment, which may reduce their immunological ability to the parasites (Poulin, 1992). Therefore, parasites are indicators of many biological aspects of the host condition (Williams et al., 1992) and they also may be important in the verification of environmental quality (Marcogliese and Cone, 1997). Therefore, parasites may complement chemical analysis or traditional biological studies as traditional indicators of dysfunctions in the ecosystem (Galli et al., 2001).

Many parasites have complex life cycles and depend on a varying number of intermediate hosts such as invertebrates and vertebrates, whereas their transmission occurs through predator-prey interactions (Overstreet, 1997). Still, when information on parasites reinforces histopathological indicators, they provide a good denotation of fish and environment health.

Black spot disease occurs after penetration of the parasite through the fish skin, which then becomes an encysted metacercariae (Lane and Morris, 2000). After this, metacercariae produces a fibrous capsule, which involves the parasite. The disease is characterised by the migration of melanocytes through the fibrous wall of the cysts, hence causing the typical appearance of black spots (Bush et al. 2001).

This study aimed to test the efficiency of the utilisation of the frequency of black spot disease caused by digenetic trematodes in assemblages of fish, featuring a new methodology that would help in the evaluation of water quality in environmental monitoring programmes.

\section{Material and Methods}

Samplings were quarterly carried out with a seine net $(15 \mathrm{~m} \times 1.5 \mathrm{~m} \times 0.5 \mathrm{~cm})$ (Malabarba and Reis, 1987), between December 2002 and December 2004, at eleven sites in the hydrographic basin of Guaiba lake (Rio Grande do Sul State, Brazil), including six sites at Guaíba lake (Point 1: Gasômetro, Porto Alegre City; Point 2; Saco da Alemoa, Eldorado do Sul Town; Point 3; Foz do arroio Celupa, Guaíba Town; Point 4; Praia da Alegria, Guaíba Town; Point 5; Barra do Ribeiro, Barra do Ribeiro Town; Point 6; Praia de Ipanema, Porto Alegre City) and five points of three tributary rivers (Point 7; Caí River, near the bridge of highway BR 386; Point 8; Caí River, near the mouth of River Jacuí; Point 9; Sinos River, near the bridge of highway BR 386; Point 10; Gravataí River, near the highway RS118; Point 11; Gravataí River, in the locality of Passo das Canoas, Figure 1).

At each site, standardised samplings were performed with four draggings along the bank. The specimens were fixed in $10 \%$ formalin in the field. In the laboratory, the material was sorted and identified in the level of species, according to Malabarba (1989) and Britski et al. (1999), and preserved in alcohol $70^{\circ} \mathrm{GL}$. Data on community composition and frequency of disease infestation were obtained for each species.

Astyanax fasciatus (Cuvier, 1819) was chosen for this study because this species presents the highest frequency and infestation degree in the study areas. Thus, ten exemplars were randomly taken from each point in order to take measurements of standard length (SL) and sex identification. Then, the amplitude of the standard length classes (SL) was established, using the Rule of Sturges (Vieira, 1991).

Histological sections were performed with samples of whole specimens infested or with only pieces of the epidermis, in order to verify probable histopathological lesions caused by parasites. The material was included and impregnated in paraffin, while 5-6 micrometer sections were made on microtome. Tissues were stained using the Hematoxylin and Eosin technique (HE). The Periodic AcidSchiff technique (PAS ) was used to verify the presence of glycogen, while the Gomori Trichrome Technique was used to observe the presence of collagenous and elastic fibres (Michalany, 1980).

The simple Chi-Square test (Zar, 1999) was applied to verify the association between the frequency of black spot disease and the study sites, in order to demonstrate whether or not there was casualness in this association. The test was applied for the entire study period (two years), as well as for each period of a sampling year, in order to observe whether or not there was repetition in the results. A principal component analysis (PCA) was performed using the following parameters: temperature, $\mathrm{pH}, \mathrm{BOD}_{5}$, dissolved $\mathrm{O}_{2}$ and coliforms thermotolerant, for the purpose of identifying which of them were influencing the quality of the body of water. The physical-chemical classification of water quality was established by the resolution number 357 of the Conselho Nacional do Meio 


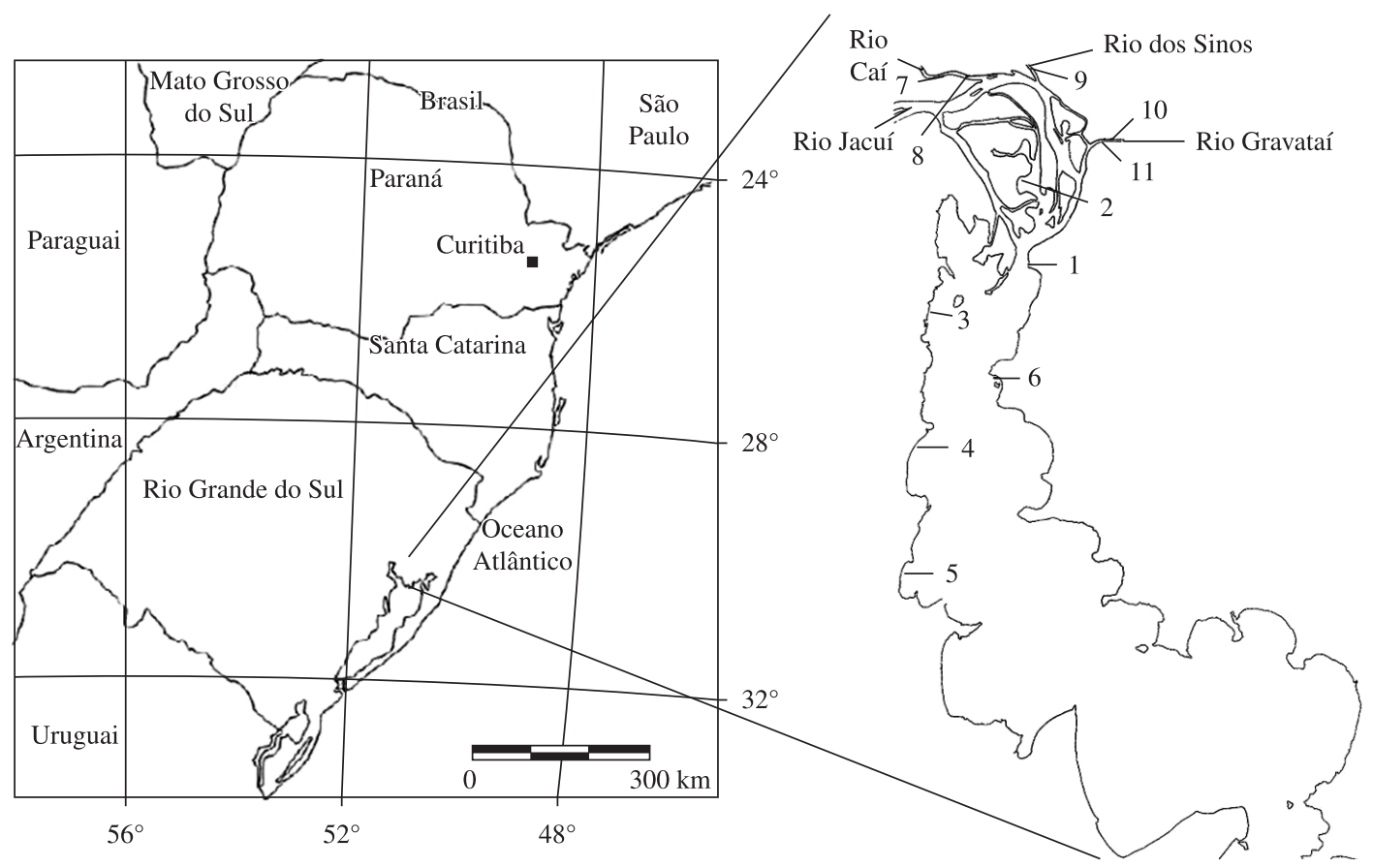

Figure 1. Map of the Rio Grande do Sul State and, in details, Lake Guaíba basin showing the flowing rivers and sampling sites. 1) Gasômetro; 2) Saco da Alemoa; 3) Foz do arroio Celupa; 4) Praia da Alegria; 5) Barra do Ribeiro; 6) Praia de Ipanema; 7) rio Caí; 8) rio Caí junto a foz com Jacuí; 9) rio dos Sinos; 10) rio Gravataí junto a RS-118 e 11) rio Gravataí na localidade de Passo das Canoas.

Ambiente, CONAMA (2005). Data for such analysis were provided by DMAE (Departamento Municipal de Água e Esgoto) with respect to Guaíba Lake, by FEPAM (Fundação Estadual de Proteção Ambiental) regarding Sinos River, and CORSAN (Companhia Riograndense de Saneamento) for all the other tributary rivers.

To investigate possible relationships between temperature (seasonality) and frequency of occurrence of black spot disease, the Spearman nonparametric statistical test was applied (Zar, 1999).

\section{Results}

A total of 53,408 samples of 66 species belonging to 22 families and eight orders of fish was collected and analysed. The most abundant families were Characidae (29\%), Loricariidae (12\%) and Cichlidae (12\%), and the most abundant species were Cheirodon ibicuhiensis Eigenmann, 1915 (21.7\%), Astyanax fasciatus (20.5\%), Hyphessobrycon luetkenii (Boulenger, 1887, 15.5\%) and Corydoras paleatus (Jenyns, 1842, 11\%).

Within the sample, 1,108 individuals had the infestation of black spot disease $(2.07 \%)$, belonging to 13 different species, considering that four of them showed results statistically significant for the chi-square test. They were: Astyanax fasciatus, A. jacuhiensis Cope, 1894, Cyphocharax voga (Hensel, 1870) and Hyphessobrycon luetkenii. Among these, the highest frequency of the disease $(8.77 \%$ ) was observed in A. fasciatus.
The total size of $A$. fasciatus specimens ranged from 15.3 to $121.7 \mathrm{~mm}$, and based on standard length measures, it was observed that $80.5 \%$ of the specimens comprising the sample were predominantly adults, ranging from $36.6 \mathrm{~mm}$ to $68.6 \mathrm{~mm}$. Males were $60.6 \%$ of the sample, and $31.6 \%$ were females, whereas $7.75 \%$ were young specimens, which impeded their identification.

Small black spots shaped like a muscle fibre and surrounding a hole formed in the epidermis of fishes indicate the infestation by the black spot disease (Figures 2a,b). Histological analysis showed that the agent causing this disease is a digenetic trematode (probably Diplostomatidae family) during the metacercariae stage. This trematode settles below the stratified epithelial tissue or beneath the dense connective tissue located just below the epithelium and above the muscle (Figure 2c). Next to the encystment, it was possible to observe the presence of immunological system cells (eosinophils, macrophages and lymphocytes) (Figure 2d). In this same region, pigmented cells (chromatophores) responsible for the formation of dark spots were observed (Figure 2d).

Just below, several fibrous layers of connective tissue surrounding the parasite were observed. These cells were produced by the host, thus characterising the fibroid that composes the encystment. According to the time of infestation, the amount of connective tissue fibres may vary from a few layers (recent encystment) to thicker fibroids (old encystment). After being stained with Gomori 

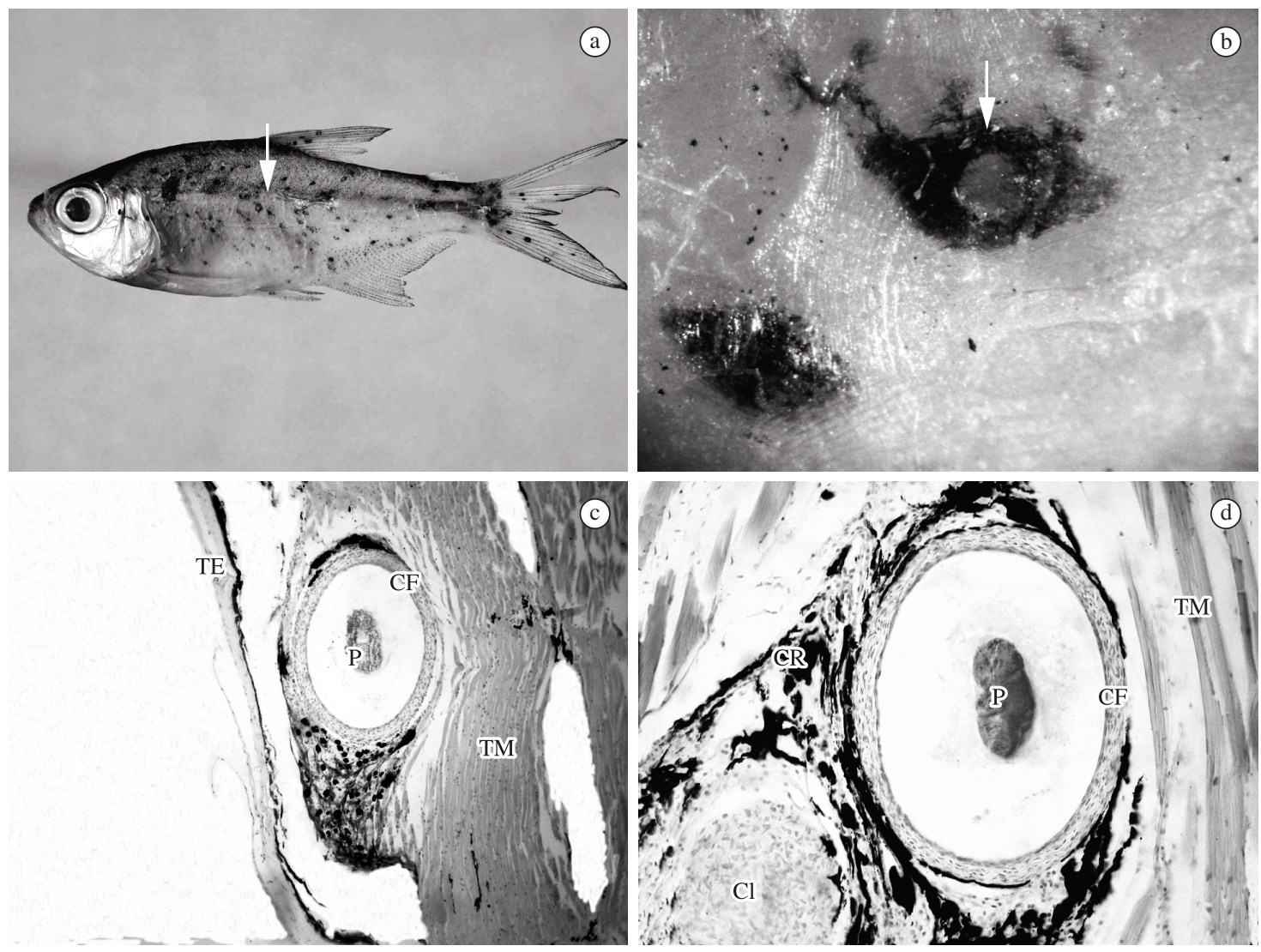

Figure 2. Black spots Disease. a) Copy of Astyanax fasciatus parasitized b) detail of black spot, c-d) photomicrographs of trematode digenetic parasites, c-d) 100×-400x; TE - Epithelial tissue; CF - Fibrous layer CR - Chromatophores; TM - Muscular tissue, P - Parasite; CI - Immune cells.

trichrome, fibres showed a positive reaction indicating the presence of collagen. Just below, a thin wall of cells was noted that showed a weakly positive reaction to PAS, indicating the presence of glycogen, mucoproteins and glycoproteins. This layer is formed by lining endothelial cells, macrophages and eosinophils. After that, the presence of two walls formed by products secreted by cystogenic glands of the parasite itself was observed, whereas the outer side was thicker and the inner side was barely visible in optical microscope (composed of elastin and collagen).

The simple Chi-square test applied to all species revealed significant results on the frequency of infected individuals in points $3,4,5$ and 6 , thereby showing no incidental infection at these sites (Table 1). When the test was specifically conducted for the species A. fasciatus, it showed significant results for the points 3,5 and 7, also showing no incidental infection in these environments (Table 2). When applied to each yearly sampling period, the simple chi-square test could be verified through a repetition of results statistically significant for the points 3 and 5, and for the watershed as a whole (Table 3).

The PCA for the physicochemical parameters showed that the parameters that most influenced the quality of water in places with higher frequency of disease occurrence in
A. fasciatus were: dissolved $\mathrm{O}_{2}$, which showed higher averages, and coliforms thermotolerant, which showed lower averages (Figure 3 and Table 4).

At points 3 and 5, the greatest changes in water temperature, higher averages of dissolved $\mathrm{O}_{2}$, and lower means of coliforms thermotolerant were verified (Figure 3). When classifying water quality, point 5 showed the lowest degradation, whereas water was considered pertaining to class I, according to the CONAMA resolution. At point 3, water was classified as class I concerning all parameters. On the other hand, point 7 was classified as class IV for coliforms thermotolerant and dissolved $\mathrm{O}_{2}$. This same point was categorised as class I with regard the other parameters. Points 1, 7, 8 and 9 were considered to have low environmental quality, given that it showed the highest average of coliforms thermotolerant and low averages of dissolved $\mathrm{O}_{2}$, thus being the point 1 categorised as class II to $\mathrm{O}_{2}$ and class IV to coliforms. The other points showed water quality ranging from good to reasonable, classified as III or IV for coliforms thermotolerant and other parameters such as class I, III or IV.

In relation to seasonality, data analysis showed no statistically significant result through Spearman's test ( $\mathrm{p}=0.4275, \mu=0.05)$ (Figure 4). 
Table 1. The simple Chi-Square test for black spot disease in all species sampled (GL $=10, \chi^{2}$ tab. $=18.31$ for $\alpha=0.05$; $\mathrm{n}=$ number of individuals, $\mathrm{f}=$ observed frequency; $\mathrm{Fi}=$ expected frequency in the sample, $\mathrm{Rf}=$ relative frequency), bold: statistically significant.

\begin{tabular}{lrrrrr}
\hline \multicolumn{1}{c}{ Local } & \multicolumn{1}{c}{$\mathbf{n}^{\mathbf{0}}$} & \multicolumn{1}{c}{$\mathbf{f}$} & \multicolumn{1}{c}{$\mathbf{F i}$} & $\boldsymbol{\chi}^{\mathbf{2}}$ & $\mathbf{R f}(\boldsymbol{\%})$ \\
\hline 1) Gasômetro & 12068 & 190 & 250.3 & 14.5 & 1.5 \\
2) S. Alemoa & 5369 & 97 & 111.3 & 1.8 & 1.8 \\
3) F. Celupa & 960 & 135 & 19.9 & $\mathbf{6 6 5 . 0}$ & 14.0 \\
4) P. Alegria & 1291 & 73 & 26.7 & $\mathbf{7 9 . 7}$ & 5.6 \\
5) B. Ribeiro & 2453 & 313 & 50.8 & $\mathbf{1 3 5 0 . 0}$ & 12.7 \\
6) P. Ipanema & 1879 & 90 & 38.9 & $\mathbf{6 6 . 7}$ & 4.7 \\
7) Caí & 992 & 6 & 20.5 & 10.3 & 0.6 \\
8) Caí-Jacuí & 3998 & 58 & 82.9 & 7.5 & 1.4 \\
9) Sinos & 1430 & 26 & 29.6 & 0.4 & 1.8 \\
10) Gravataí118 & 6069 & 28 & 125.9 & 76.1 & 0.4 \\
11) GravataíPC & 16899 & 92 & 350.5 & 190.7 & 0.5 \\
& 53408 & 1108 & & $\mathbf{2 4 6 3 . 0}$ & 2.0 \\
\hline
\end{tabular}

Table 2. The simple Chi-Square test for black spot disease in species A. fasciatus (GL $=10, \chi^{2}$ tab. $=18.31$ for $\alpha=0.05$, $\mathrm{n}=$ number of individuals, $\mathrm{F}=$ observed frequency; $\mathrm{Fi}=$ expected frequency in the sample, $\mathrm{Rf}=$ relative frequency), bold = statistically significant.

\begin{tabular}{lrrrrr}
\hline \multicolumn{1}{c}{ Local } & $\mathbf{n}^{\mathbf{0}}$ & $\mathbf{F}$ & $\mathbf{F i}$ & \multicolumn{1}{c}{$\boldsymbol{\chi}^{\mathbf{2}}$} & $\mathbf{R f}(\boldsymbol{\%})$ \\
\hline Gasômetro & 4834 & 168 & 424.0 & 154.6 & 3.4 \\
S. Alemoa & 1208 & 74 & 105.9 & 9.6 & 6.1 \\
F. Celupa & 477 & 134 & 41.8 & $\mathbf{2 0 2 . 9}$ & 28.0 \\
P. Alegria & 590 & 70 & 51.7 & 6.4 & 11.8 \\
B. Ribeiro & 1029 & 301 & 90.2 & $\mathbf{4 9 1 . 9}$ & 29.2 \\
P. Ipanema & 884 & 87 & 77.5 & 1.15 & 9.8 \\
Caí & 10 & 5 & 0.8 & $\mathbf{1 9 . 3}$ & 50 \\
Caí-Jacuí & 677 & 55 & 59.3 & 0.3 & 8.1 \\
Sinos & 283 & 20 & 24.8 & 0.9 & 7.0 \\
Gravataí118 & 141 & 6 & 12.3 & 3.2 & 4.2 \\
GravataíPC & 822 & 41 & 72.1 & 13.4 & 4.9 \\
& 10955 & 961 & & $\mathbf{9 0 4 . 1}$ & 8.7 \\
\hline
\end{tabular}

Table 3. The single Chi-square test for species A. fasciatus in the two sampling periods (GL $=10, \chi^{2}$ tab. $=18.31$ for $\alpha=0.05$, $\mathrm{n}=$ number of individuals, $\mathrm{f}=$ observed frequency; $\mathrm{Fi}=$ expected frequency in the sample), bold = significant statistically.

\begin{tabular}{lrrrrrrrrr}
\hline \multicolumn{1}{c}{ Year 1 } & $\mathbf{n}$ & \multicolumn{1}{c}{$\mathbf{f}$} & \multicolumn{1}{c}{$\mathbf{F i}$} & \multicolumn{1}{c}{$\boldsymbol{\chi}^{\mathbf{2}}$} & Year 2 & $\mathbf{N}$ & \multicolumn{1}{c}{$\mathbf{f}$} & \multicolumn{1}{c}{$\mathbf{F i}$} & \multicolumn{1}{c}{$\boldsymbol{\chi}^{\mathbf{2}}$} \\
\hline Gasômetro & 2433 & 10 & 226.3 & 206.7 & Gasômetro & 2401 & 158 & 197.6 & 7.9 \\
S. Alemoa & 645 & 10 & 59.9 & 41.6 & S. Alemoa & 563 & 64 & 46.3 & 6.7 \\
F. Celupa & 335 & 107 & 31.1 & $\mathbf{1 8 4 . 5 *}$ & F. Celupa & 142 & 27 & 11.6 & $\mathbf{2 0 . 0}$ \\
P. Alegria & 356 & 41 & 33.1 & 1.8 & P. Alegria & 234 & 29 & 19.2 & 4.9 \\
B. Ribeiro & 752 & 249 & 69.9 & $\mathbf{4 5 8 . 3}$ & B. Ribeiro & 277 & 52 & 22.8 & $\mathbf{3 7 . 3}$ \\
P. Ipanema & 313 & 10 & 29.1 & 12.5 & P. Ipanema & 571 & 77 & 47.0 & 19.1 \\
Caí & 8 & 5 & 0.7 & $\mathbf{2 4 . 3}$ & Caí & 2 & 0 & 0.1 & 0.1 \\
Caí-Jacuí & 295 & 45 & 27.4 & 11.2 & Caí-Jacuí & 382 & 10 & 31.4 & 14.6 \\
Sinos & 162 & 19 & 15.0 & 1.0 & Sinos & 121 & 1 & 9.9 & 8.0 \\
Gravataí118 & 73 & 3 & 6.7 & 2.1 & Gravataí118 & 68 & 3 & 5.6 & 1.2 \\
GravataíPC & 154 & 15 & 14.3 & 0.03 & GravataíPC & 668 & 26 & 55.0 & 15.2 \\
& 5526 & 514 & & $\mathbf{9 4 4 . 5}$ & & 5429 & 447 & & $\mathbf{1 3 5 . 5}$ \\
\hline
\end{tabular}




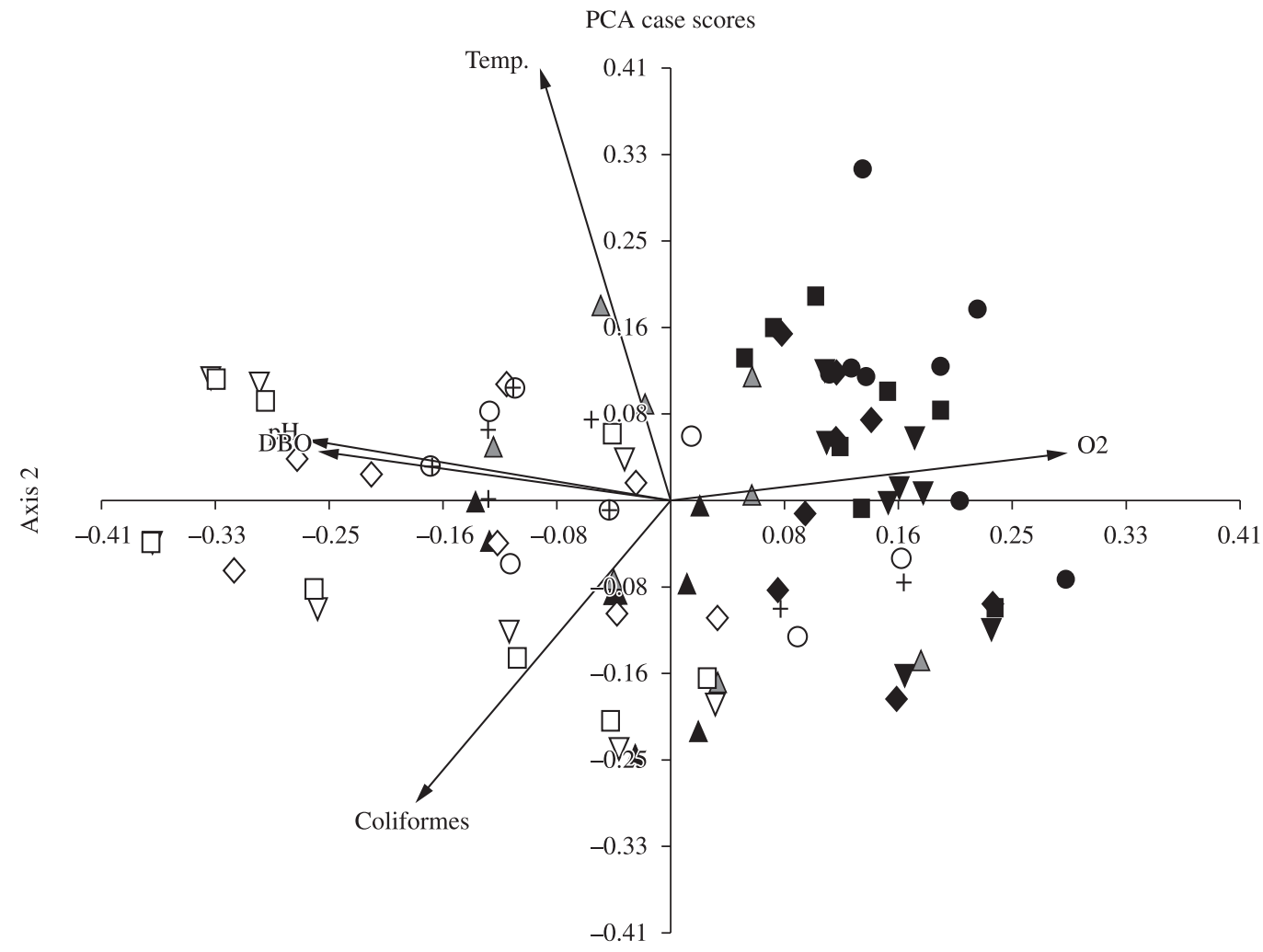

Vector scaling: 0,51

Axis 1

$\begin{array}{lllll}\Delta \text { Gasometro } & \boldsymbol{\nabla} \text { S. Alemoa } & \boldsymbol{B} \text { F. Celupa } & \diamond \text { P. Alegria } & \bullet \text { B. Ribeiro } \Delta \text { P. Ipanema } \\ \nabla \text { Caí } & \square \text { Caí-Jacuí } & \diamond \text { Sinos } & \text { O Gravataí118 } & + \text { GravataíPC }\end{array}$

Figure 3. Principal components analysis of the physicochemical parameters observed in the sampling spots.

Table 4. Values of the average physico-chemical parameters analyzed for each sampling point throughout the study period in the hydrographic basin of Lake Guaíba. $\mathrm{pH}=$ potential hydrogen; $\mathrm{O}_{2}=$ dissolved oxygen $\left(\mathrm{mg} \cdot \mathrm{L}^{-1} \mathrm{O}_{2}\right), \mathrm{BOD}_{5}=$ biochemical oxygen demand $\left(\mathrm{mg} . \mathrm{L}^{-1} \mathrm{O}_{2}\right)$; col. therm. = coliforms thermotolerant (units per $\left.100 \mathrm{~mm}\right)$; temp $=$ temperature $\left({ }^{\circ} \mathrm{C}\right)$.

\begin{tabular}{lccccc}
\hline \multicolumn{1}{c}{ Local } & $\mathbf{p H}$ & $\mathbf{O}_{2}$ & $\mathbf{D B O}_{5}$ & Col. Therm. & Temp. \\
\hline Gasômetro & $6.9( \pm 0.21)$ & $5.7( \pm 1.46)$ & $2.2( \pm 1.3)$ & $17375( \pm 13935)$ & $20( \pm 3.78)$ \\
S. Alemoa & $7.1( \pm 0.21)$ & $7.7( \pm 0.86)$ & $0.5( \pm 0.27)$ & $171.6( \pm 160)$ & $20.2( \pm 4.1)$ \\
F. Celupa & $7.6( \pm 0.4)$ & $7.2( \pm 0.84)$ & $1.4( \pm 0.77)$ & $13.1( \pm 471)$ & $21.2( \pm 4.03)$ \\
P. Alegria & $7( \pm 0.18)$ & $7.7( \pm 0.95)$ & $0.7( \pm 0.22)$ & $1063.3( \pm 2111)$ & $21.3( \pm 4.9)$ \\
B. Ribeiro & $7.4( \pm 0.38)$ & $8.2( \pm 0.99)$ & $0.8( \pm 0.37)$ & $12.5( \pm 15.61)$ & $23( \pm 5.37)$ \\
P. Ipanema & $7.1( \pm 0.23)$ & $6.9( \pm 1.1)$ & $1.6( \pm 0.74)$ & $9982.5( \pm 12767)$ & $24.2( \pm 6.43)$ \\
Caí & $7.0( \pm 0.07)$ & $2.7( \pm 0.7)$ & $2( \pm 1.68)$ & $18122.5( \pm 30612)$ & $20( \pm 4.41)$ \\
Caí-Jacuí & $6.9( \pm 0.07)$ & $2.7( \pm 0.7)$ & $2( \pm 1.68)$ & $18122.5( \pm 30612)$ & $20.2( \pm 4.03)$ \\
Sinos & $7.1( \pm 0.12)$ & $3.1( \pm 0.97)$ & $1.8( \pm 0.83)$ & $910( \pm 1046)$ & $20.2( \pm 3.77)$ \\
GravataíRS118 & $6.4( \pm 0.65)$ & $5.3( \pm 1.11)$ & $1.2( \pm 0.52)$ & $993.3( \pm 1261)$ & $20.8( \pm 3.4)$ \\
GravataíPC & $7.3( \pm 0.13)$ & $5.3( \pm 1.11)$ & $1.2( \pm 0.52)$ & $993.3( \pm 1261)$ & $21.1( \pm 3.23)$ \\
\hline
\end{tabular}




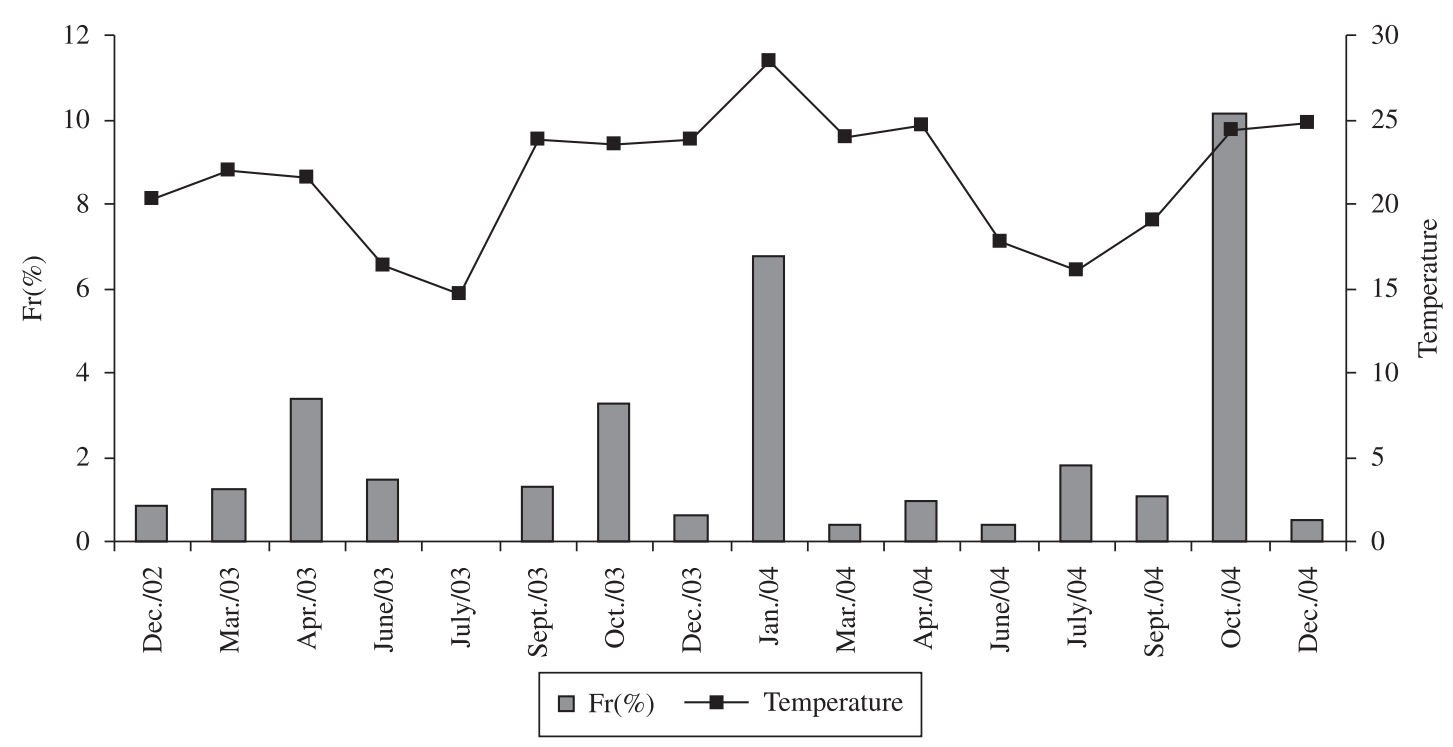

Figure 4. Relationship between the relative frequency of disease infestation and temperature during the sampling period in the basin of Lake Guaíba. Temp = temperature; Fr $(\%)=$ Relative frequency.

\section{Discussion}

It was observed in this study that fish responded to the presence of parasites with an encapsulation formed by cellular involucres around the parasite, which can be fragile or resistant, sometimes consisting of many concentric layers of cells derived mainly from connective tissue, as described by Flores-Lopes et al. (2002) and Rohde (1984), where a separate capsule originating from the host is formed. Metacercariae infestation is extremely common in fish and most often results in severe injuries for the hosts (Rohde, 1984).

The result of the chi-square test showed no incidental occurrence of the black spot disease in points 3 and 5 for the species A. fasciatus. Furthermore, the results obtained by PCA for the physicochemical parameters showed that the lowest means of coliforms thermotolerant and the highest means of dissolved $\mathrm{O}_{2}$ occurred in these ecosystems, hence contributing to the categorisation of these places as class I, by the CONAMA resolution. The association between high frequency of infestation by the parasites causing the black spot disease and the best quality of the physicochemical parameters, as well as the repetition of the results in two sampling periods may, therefore, be considered an indicator of water quality in these environments.

Similar results were observed by Flores-Lopes and Thomaz (2011) when histologically analysing the gills of A. fasciatus. These authors observed a higher frequency of moderate intensity changes in point 3 and only slight changes in 5. Moreover, another study (Flores-Lopes and Reuss-Strenzel, 2011) on the morphological changes could verify that point 3 did not show statistically significant result by chi-square test. Studying the composition of fish fauna, Flores-Lopes et al. (2010) found that point 5 showed the diversity index more regularly during the sampling period, thereby being classified as quality mean by integrated quality index.

The categorization of water in classes established by the resolution 357 of CONAMA was used in this work. Galli et al. (2001), conducted studies on water quality as a determinant factor in the composition of the community of fish parasites; such studies used a ranking system per classes, where class I refers to better water quality and class IV refers to the most deteriorated class, being similar to the classification used in this work. These authors reported data similar to those observed in this study for the coliform total and thermotolerant and dissolved $\mathrm{O}_{2}$ parameters, thus verifying that the smallest abundance of parasites was seen in the heavily polluted sites. When associated with high frequencies of infection by metacercariae of parasites, this information can be considered as an indicator of lower environmental degradation.

Results of this study indicate that pollution may influence the prevalence and abundance of parasites, corroborating the results obtained by Galli et al. (2001) for prevalence and abundance of parasites in polluted sites, who found that the amount of digenetics such as Diplostomun spathaceum and Asymphylodora tincae have decreased in areas heavily polluted and showed higher infestation indices at sites moderately polluted. For Overstreet (1997), parasites that include more than one host in its life cycle usually occur in low numbers in contaminated soils. This may occur depending on the contaminant either to reduce or eliminate their intermediate or final hosts, or for the contaminants to have a direct toxic effect on the parasite. Janovy et al. (1997) have reported that the prevalence and abundance of various metacercariae of digenetic factors like those that cause cataracts in fish, increase in low quality in lentic waters. Small differences in prevalence and abundance of 
fish parasites have great ecological importance, given that they are easier to perceive than small chemical changes in blood and in swimming behaviour (Poulin, 1992).

Results from this study corroborate the results obtained by Koskivaara (1992), for whom the parasites of fishes are particularly interesting, given that both are in direct contact both with the hosts and with the environment that surrounds them, thereby promoting information about the effects of environmental conditions on the organism of the hosts.

It was observed that the relative frequency of the trematode originator of the black spot disease has significantly decreased in places with greater water degradation. Pollutants and other anthropical changes in aquatic environments may directly affect the community of parasites, acting in the free-living beings or in the ectoparasitics, or even working indirectly in the definitive and intermediate hosts (Möller, 1987). According to the author, some pollution conditions favour the spread of parasites because they abolish their natural predators, reduce the resistance of the hosts or promote unfavourable life conditions for the intermediate hosts. This same researcher also highlights that several studies on parasites have shown how these beings are likely to suffer high mortality rates when exposed to high temperatures, low oxygen level, or high levels of heavy metals dissolved, when compared with nonparasite animals. Kennedy (1997) showed that parasites may be affected by changes in the pattern of presence and abundance of distribution of their definitive or intermediate hosts. Besides that, the lack of parasites may indicate the presence of toxins in this habitat for weeks or years in this habitat (Overstreet, 1997).

Slobodkin (1967) has suggested that the response of an organism to a non-catastrophic disturbance will usually result in a decrease or an increase in survivability. By bringing together the results of this study and those obtained in other studies, it is possible to verify that parasites may be used as a complementary tool to physicochemical analysis or to traditional biological tests of survival, given that they are used as indicators of ecosystem dysfunctions.

This study suggests that the high frequency of the parasite causing the black spot disease can indicate less degraded environments, and as such, it potentially indicates better environmental quality. Studies in this area are still recent and require further research in order to promote understanding on the complex mechanisms of the hostparasite relation with environmental pollution.

Acknowledgements - We thank our colleagues from the Laboratory of Ichthyology at UFRGS for field work support. CNPq provided a fellowship to FFL (proc. 476821/2003-7). We would like to thank Profa. Márcia Alexandra Rocca de Andrade for reviewing the English language.

\section{References}

BARBOUR, MT., GERRITSEN, J., SNYDER, BD. and STRIBLING, JB., 1999. Rapid Bioassessment Protocols for use in streams and Wadeable Rivers: Peryphyton, Benthic Macroinvertebrates and
Fish. 2nd ed. Washington: Environmental Protection Agency. 339 p. U.S EPA 841-B-99-002.

BRITSKI, HA., SILIMON, KAS. and LOPES, BS., 1999. Peixes do Pantanal: Manual de Identificação. Brasilia: Embrapa-SPI; Corumbá: Embrapa-CPAP. 184 p.

BRUSCHI JUNIOR, W., MALABARBA, LR. and SILVA, JFP., 2000. Avaliação da Qualidade Ambiental dos riachos através das Taxocenoses de peixes. In: Universidade Federal do Rio Grande do Sul. Centro de Ecologia. Carvão e Meio Ambiente. Porto Alegre: Ed. da ufrgs. p. 803-809.

BUSH, AO., FERNANDEZ, JC., ESCH, GW. and SEED, JUNIOR, 2001. Parasitism: the diversity and ecology of animal parasites. Cambridge: Cambridge Univ. Press. 312 p.

Conselho Nacional do Meio Ambiente, 2005. Resolução n 357 de 17 de março de 2005. Dispõe sobre a classificação dos corpos de água e diretrizes ambientais para o seu enquadramento, bem como estabelece condições e padrões de lançamento de efluentes. Diário Oficial da República Federativa do Brasil, Brasília, DF, 17 mar. 2005.

ESCH, GW., GIBBONS, JW. and BOURQUE, JE., 1974. An Analysis of the Relationship Between Stress and Parasitism. The American Midland Naturalist, vol. 93, no. 2, p. 339-353.

FLORES-LOPES, F., CETRA, M. and MALABARBA, LR. 2010. Utilização de índices ecológicos em assembléias de peixes como instrumento de avaliação da degradação ambiental em programs de monitoramento. Biota Neotropica, vol. 10, no. 4 http://www. biotaneotropica.org.br/v10n4/en/abstract?article+bn03710042010

FLORES-LOPES, F., MALABARBA, LR., DA SILVA, JFP. and PEREIRA, EHL., 2002. Histologia de deformidades vertebrais em Astyanax alburnus (Hensel, 1870) (Ostariophysi: Characidae) do lago Guaíba, Rio Grande do Sul, Brasil. Comunicações do Museu de Ciências e Tecnologia da PUCRS, Série Zoologia, vol. 15 , no. 1, p. 137-155.

FLORES-LOPES, F. and THOMAZ, AT., 2011. Histopathologic alterations observed in fish gills as a tool in environmental monitoring. Brazilian Journal of Biology, vol. 71, no. 1, p. 179-188.

FLORES-LOPES, F. and REUSS-STRENZEL, GM. 2011. Frequency of morphological alterations in the fish of Lake Guaíba and its application to environmental monitoring. Bioikos, vol. 25, no. 1, p. 11-23

GALLI, P., CROSA, G., MARINIELLO, L., ORTIS, M. and D'AMELIO, S., 2001. Water quality as a determinant of the composition of fish parasite communities. Hydrobiologia, vol. 452, p. 173-179. http://dx.doi.org/10.1023/A:1011958422446

GIBSON, GR., BARBOUR, MT., STHIBLING, JB., GERRITSEN, J. and KARR, JR., 1996. Biological criteria: Thechnical guidance for streams and small rivers. rev. ed. Washington: Environmental Protection Agency. 339 p. EPA 822-B-96 001.

JANOVY JUNIOR, J., SNYDER, SD. and CLOPTON, RE., 1997. Evolutionary constraints on population structure: the parasites of Fundulus zebrinus (Pisces: Cyprinodontidae) in the South Platte River of Nebraska. Journal of Parasitology, vol. 83, p. 584-592. PMid:9267396. http://dx.doi.org/10.2307/3284228

KENNEDY, CR., 1997. Fresh water fish parasites and environmental quality: an overview and caution. Parassitologia, vol. 39, p. 249-254.

KOSKIVAARA, M., 1992. Environmental Factors Affecting Monogeneans Parasitic on Freshwater Fishes. Parasitology 
Today, vol. 8, n. 10, 339-342. http://dx.doi.org/10.1016/01694758(92)90069-E

LANE, RL. and MORRIS, JE., 2000. Biology, prevention and effects of common grubs (digenetic trematodes) in freshwater fish. Iowa: Iowa State University. (Tech Bull Series, no. 115).

LOBO, EA., CALLEGARO, VLM. and BENDER, EP., 2002. Utilização de algas diatomáceas epilíticas como indicadores da qualidade da água em rios e arroios da região hidrográfica do Guaíba, RS, Brasil. Santa Cruz do Sul: EDUNISC. 127 p.

MALABARBA, LR. 1989. Histórico Sistemático e Lista Comentada das Espécies de Peixes de água doce do Sistema da Laguna dos Patos. Comunicações do Museu de Ciências da PUCRS, v. 2, n. $8,107-179$.

MALABARBA, LR. and REIS, RE., 1987. Manual de Técnicas para a preparação de Coleções Zoológicas. Campinas: Sociedade Brasileira de Zoologia. no. 36 - Peixes, 14 p.

MARCOGLIESE, DJ. and CONE, DK., 1997. Parasite communities as indicators of ecosystem stress. Parassitologia, vol. 39, p. 227-232.

MICHALANY, J., 1980. Técnica histológica em Anatomia Patológica, com instruções para o cirurgião, enfermeira e citotécnico. São Paulo: EPU. 277 p.
MÖLLER, H., 1987. Pollution and parasitism in the aquatic environment. International Journal of Parasitology, vol. 17, p. 353-361. http://dx.doi.org/10.1016/0020-7519(87)90110-X

OVERSTREET, RM., 1997. Parasitological data as monitors of environmental health. Parassitologia, vol. 39, p. 169-175.

POULIN, R., 1992. Toxic Pollution and Parasitism in Freshwater Fish. Parasitology Today, vol. 8, no. 2, p. 58-61. http://dx.doi. org/10.1016/0169-4758(92)90090-O

ROHDE, K., 1984. Diseases caused by metazoans: Helminths. In: Kinne, O. Diseases of Marine Animals. Hamburg: Biologische Anstalt Helgoland. vol. 4, no. 1 - Pisces, p. 193-320.

SLOBODKIN, LB., 1967. Toward a predictive theory of evolution. In: Lewontin, rc. (Ed.). Population biology and evolution. Syracuse: Univ. Press. p. 187-205.

VIEIRA, S., 1991. Introdução à Bioestatística. 2nd ed. Rio de Janeiro: Ed. Campus. 294 p.

WILLIAMS, HH., MACKENZIE, K. and MACCARTHY, AM., 1992. Parasites as biological indicators of the population biology, migration, diet and phylogenetics of fish. Reviews in Fish Biology and Fisheries, vol. 2, 144-176. http://dx.doi.org/10.1007/ BF00042882

ZAR, JH., 1999. Biostatistical Analysis. 4nd ed. Northern Illinois University. New Jersey: Prentice-Hall. 663 p. 
